\title{
12. A case for Fiji's grassroots citizenry and media to be better informed, engaged for democracy
}

\section{ABSSIRACI}

Democracy in Fiji has been top-down where primarily the middle class and the wealthy elite have understood its true merits and values. Politicians, professionals, academics and civil society organisations, rather than the grassroots population, have been at the forefront of advocating against coups. Democracy was described as a 'foreign flower' by ethno-nationalists for two decades. Some critics see it as having failed to work properly in Fiji because a lack of infrastructure and development means grassroots people are not sufficiently informed to make critical decisions and hold leaders accountable. This, and a lack of unity, led to a failure of widespread protests against coups. Civil society, political activists and individuals were isolated in their struggle against coups. The media has been a key player in anti-coup protests as it relayed information that enabled networking and partnership. Media censorship since April 2009 has restricted their role and violated citizens' Right to Information. This article argues that for democracy to work, the infrastructure and communications technology needs to reach the masses so people are adequately informed through an uncensored media.

Keywords: civil society, communications technology, democracy, development, grassroots, political activism

\section{MOSMI BHIM}

Civil Society Advocate, Fiji

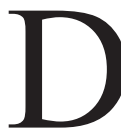

EMOCRACY in Fiji has been top-down where primarily the middle class and the rich have understood its true merits and values. Politicians, professionals, academics and civil society organisations, rather than the grassroots population, have been at the forefront of advocating against coups. Democracy was described as a 'foreign flower' by 
ethnonationalists for two decades. Now many of them believe elections are the right way to choose Fiji's leaders. The 5 December 2006 coup has thrown up a series of complex questions about democracy as some advocates for equal rights and democracy gave their support to coup-makers, and as ethnonationalist politicians turned against an indigenous Fijian coup-maker.

Past elections in Fiji have been won on votes cast in response to emotional appeals by politicians as opposed to criteria based on better services and accountability of the government. The lack of widespread protests against coups is seen in the context of the need for basic services at the grassroots level, including the lack of infrastructure (roads, water, electricity and telecommunications) and its contribution to the malfunctioning of democratic processes in Fiji through a citizenry that is not adequately informed by media or research. A lack of good leaders has contributed to this problem, as has the discomfort experienced by ordinary citizens when seeking accountability and transparency from their leaders. The comprehension of ordinary citizens is essential for democracy to work, as is a realisation of economic, social and cultural rights.

Civil society, political activists and individuals were isolated in their struggle against coups. The media has been a key player in anti-coup protests as it relayed information that enabled networking and partnership. Media censorship since April 2009 has restricted their role and violated citizens' Right to Information. This article argues that for democracy to work, the infrastructure and communications technology needs to reach the masses so people are adequately informed through an uncensored media. Civil society, politicians and individuals need to unite to fight for democracy.

\section{Nature of democracy in Fiji}

The nature of democracy in Fiji is a system introduced by departing colonisers after a century of colonisation, and 'Fijianisation' of Christianity. Asesela Ravuvu (Ravuvu, 1991) talks at length of how Fijians were colonised, tamed and rebellions controlled. After Cession in 1874,

Fijian chiefs were generally unhappy that their once despotic authority had been curtailed by the presence of the colonial government. Now and then they would reassert their authority by disobeying certain arbitrary orders of the colonial administrators'... Chiefs and people who disobeyed orders by government officials were usually severely dealt with. They were either put under custody or deported to other remote 
and foreign areas in Fiji away from sight and support of their kinsmen. Some were placed in European plantations to work out their penalties, and some were tried and executed. (Ravuvu, 1991, pp. 18-19)

Fijians were thus subjugated and colonised by the British. Indian indentured labourers brought to Fiji to work in sugar cane plantations from 1874, were over-worked and suffered unimaginable abuse and indignities. Descendents of the Indian indentured labour force began struggling for democracy as early as the 1920s. Indians went on strike in 1920 and 1921 to demand for an increase in wages. It is said Indians understood democracy better due to India's colonial legacy and the fight for independence going in the motherland. Indians were keenly aware of being discriminated against and the need to work to establish themselves in this new land, far away from the country of their ancestors.

Indians continued struggling for equal rights and in 1929 moved a motion for common roll. The colonial government reacted to this by granting the franchise to Indians, but the Fijians remained without franchise. While Indians elected their leaders, the Fijian leaders were selected by the Great Council of Chiefs. However, ordinary Fijians did not fight for their right to vote, they were granted the right to vote in the 1960s.

Fijians did not struggle for independence and equal rights after colonisation. This means Fijians have yet to undergo the civil and political revolution often necessary to establish democracy. The coups in Fiji could symbolise the anti-colonial struggle for democracy by Fijians as it has been directed against the perceived ruling class. Each country goes through its own cycles of peace and revolutions to achieve democracy. The 2006 coup is seen as a struggle against the chiefs and Fijian elites who established a stronghold since the 1987 coup. This view is echoed by Dr Satish Chand in a paper where he argues that Fiji is on a 'rocky road of coups to democracy' (Chand, 2009, p. 1). The paper was withdrawn by Chand after it received widespread criticism from fellow academics. Chand argues that Fiji never was a real democracy, that each of the coups has moved Fiji closer towards a representative democracy, and that Fiji is as close as ever to bringing about democratic reforms (ibid.). If this interpretation of modernisation theory is correct, then true sustainable democracy may be achieved in Fiji after ordinary Fijians make a revolution to realise their rights. 


\section{Grassroots remain voiceless}

The elections in Fiji are fought on the grounds on ethnicity, values and fears of the ordinary people. The parties who win are those that show that they indentify with the common people - to do this, they must not only show a ready understanding of their basic needs of low cost food items, water, health, education and infrastructure facilities, but also of culture, traditions and economic safeguards. An analysis of the 2001 elections results reveal that political parties exploited to the full the different customs and traditions of the races and cultures in Fiji.

The winners were the political parties that most successfully exploited and manipulated traditional, ethnic, cultural and religious influences. Overall, these influences compartmentalised the voters making them less free to express their will. (Yabaki, 2009, p. 401)

The 2006 election results were found to have the same trend as the 2001 . Fiji's elections have been unkind to reformed politicians who publicly acknowledge wrongs. Those who once supported ethno-nationalist policies but came to embrace multiracialism have been treated poorly at the polls by their people. For example, Sitiveni Rabuka, Ratu Meli Vesikula, and Ratu Epeli Ganilau have all suffered electoral defeat after embracing multiculturalism. Jai Ram Reddy was voted out after the National Federation Party (NFP) formed a coalition with coup-maker Rabuka's party Soqosoqo ni Vakavulewa ni Taukei. Fiji's society is not providing space for politicians to hold different views, as should be the case in a democracy.

Elections are not providing leaders who are truly responsive to the needs of the people. Elections are also not providing leaders with vision and integrity. This means that democracy in Fiji has not worked because it has not reached the grassroots. The growing educated middle-class of all races enjoy democracy as they are privy to the knowledge base which, with an informed society, is a prerequisite for proper functioning of a democracy. It was largely the middle class, or those with the capability of climbing up the social ladder, that participated in elections and were candidates, and who represent the professions of accountants, lawyers, doctors, teachers, small-business owners, academics, and communications workers. It is mainly from this class that the 'human rights activists' and democracy defenders also tend to come from. 
The grassroots seem unable to put themselves forward as candidates who have integrity and vision. They are dependent on civil society organisations (CSOs) articulating their needs. This is a common problem in Third World countries. Some CSOs are introducing initiatives to teach how citizenship can be claimed and rights realised through the actions and agencies of people themselves (Kabeer, 2005) in countries such as Bangladesh, Brazil, Britain, Nigeria, Peru, Rajasthan, South Africa and the United States. It is hoped that such education will make 'institutions more responsive to the needs and voices of poor people'.

A lack of critical citizens can result in elections being won by mediocre candidates put forward by political parties, as has been the case in Fiji and other South Pacific countries. The democracy defenders and politicians are from the middle class, which means poor leadership is located in this class. The question many ask is how do leaders benefit if the grassroots population remain underdeveloped and uninformed?

\section{Failure of widespread protest against coups}

After the 1987 coup, a group of democracy advocates emerged, steadfast in their protest, comprising of academics such as Vijay Naidu, Wadan Narsey, Claire Slatter, Sitiveni Ratuva, women's rights activists such as Peni Moore, Shamima Ali, Imrana Jalal, and also the late Amelia Rokotuivuna and lawyer Richard Naidu. Many others, such as Dr Anirudh Singh who was abducted and tortured by the military, resulting in hospitalisation after the 1987 coup, have also been involved, but the names mentioned above were more widely known. Their struggle was based on standing up for what they felt was morally right. The rights-based non-government organisations (NGOs) had been vocal opponents of the 1987 and 2000 coups, many putting their activists' safety at risk by voicing concern against human rights abuses.

The 19 May 2000 coup saw a more organised response from activists. By then there was an NGO Coalition on Human Rights (NGOCHR) comprising of Aids Taskforce, Citizens' Constitutional Forum (CCF), Ecumenical Centre for Research Education and Advocacy (ECREA), fem'link Pacific, Fiji Disabled People's Association (FDPA), Fiji Human Rights Commission (FHRC), Fiji I Care, Fiji Trades Union Congress (FTUC), Fiji Women's Crisis Centre (FWCC), Fiji Women's Rights Movement (FWRM), Fiji Young Lawyers Association (FYLA), Greenpeace Pacific, National Council for Women in Fiji 
(NCWF), Pacific Islands Association of NGOs (PIANGO), Regional Rights Resource Team (RRRT), Women's Action for Change (WAC), Equal Ground Pasifik, and the Pacific Concerns Resource Centre (PCRC).

The NGOCHR has been administered by a rotating secretariat. The first secretariat in 1997 was the FWCC. In June 1999, the Secretariat moved to CCF with director Reverend Akuila Yabaki as chairperson. In June 2006, the Secretariat moved to FWRM. Only rights-based NGOs, including CCF, FWCC, WAC, Fem'link, ECREA, and FWRM, participated in anti-coup protests.

The CSOs with a large membership of ordinary citizens tend to refrain from making anti-coup statements. These include workers and teachers' unions which have large memberships and tend to align at strategic times with political parties. These CSOs have done their share of protesting, but stop when their members' livelihoods, or their own jobs, are put at high risk.

\title{
Perceived discord within the NGOCHR
}

In the aftermath of the 5 December 2006 coup, there was a perceived discord within the NGOCHR, which was evident in the lack of a media release. Instead, there was a news release on 7 December 2006 from the newly created Coalition for Democracy and Peace. The chair of the NGOCHR, Virisila Buadromo, explains:

\begin{abstract}
There was no issue about getting the NGOCHR together to put out a statement following the coup. The issue was that there were concerned citizens and organisations [which] were against the coup; they joined the NGOCHR meetings in support of democracy and the rule of law and the overthrow of the elected government. (V. Buadromo, interview with author, 12 December 2007)
\end{abstract}

The coalition was strongly supported by FWCC, FWRM, Pacific Centre for Public Integrity (PCPI), and Fem'Link Pacific and held regular meetings in December 2006, through which an action plan was prepared. The Coalition prepared a 'Call for a Presidential Commission of Truth, Justice and Resolution' which would have established an inquiry going back to the events of 2000 , to 'clarify the truth regarding the events of 2000 attempted coups and mutiny; clarify the constitutional issues raised by the post-2000 events leading to the current impasse', make fair judgement holding national interest paramount, make recommendations on demands presented by Republic of 
Fiji Military Forces (RFMF), 'make any other recommendations as it sees fit to ensure that there is Sustainable and Just Resolution of the current crisis; end this abhorrent cycle of coups'.

The Coalition fully supported the deposed Prime Minister Laisenia Qarase and did not accept that the RFMF had 'any authority from the people of Fiji for their current actions in forcing the removal of a constitutionally elected government'. The Coalition proposed 14 members for the Presidential Commission.

The Coalition lasted three weeks and no communication was received after Christmas 2006. Buadromo explains that, 'initially, there was a lot of support, unfortunately since the coup occurred in December and it was the holiday season and maybe people either went away for holidays or offices closed for the festive season... As such, it ended up being very few organisations and individuals who continued to pressure the regime.' (Buadromo, 2007).

The lack of coverage by the media on NGO statements created a feeling of a lack of reaction from NGOs on the coup and that discord existed. The real rift occurred after the abduction and torture of a group of young activists on Christmas Eve in 2006, including Virisila Buadromo. The appearance of a lack of swift reaction from NGOs creates a sense of betrayal, compounded by selective media reporting. The impact on Buadromo was traumatic, and the NGOCHR was not reconvened until months afterwards.

Salt was added to wounds by FHRC Director Shaista Shameem who had played a leading role in protests against human rights abuses during the 56-day hostage crisis of the 2000 coup. Dr Shameem's paper released on 4 January 2007 justified Frank Bainimarama's military takeover on the grounds of the 'doctrine of necessity' (Shameem, 2007). The paper argued that as the lawful government deposed in the 2000 coup was not returned to power, all subsequent governments were 'unconstitutional'. The paper highlighted policies of the Soqosoqo ni Duavata ni Lewenivanua (SDL) government from 2001 to 2006 which it rationalised as unconstitutional because of breach of various human rights. The alleged improper conduct of the 2006 elections, comprising various irregularities and voter registration discrepancies, is cited as the 2006 government was not legitimately elected (Shameem, 2007). The paper outraged NGOs and increased the rift within the NGOCHR.

The division grew stronger after the swearing in of Bainimarama as interim PM on 5 January 2007. NGOs such as ECREA, working with marginalised 
and poor communities 'who suffered under the SDL government' were not forthcoming in criticising the coup. New activists were accused of being political party supporters. A regional NGO, PCRC, which had left the coalition after the 2000 coup, rejoined in 2007 to protest against the 2006 coup. WAC resigned from the coalition on what it terms as 'personal and political' agendas dominating the coalition.

A few NGOs took a hardline stance of non-engagement and outright condemnation of the new interim regime (FWRM, FWCC, PCPI and Femlink'). NGOCHR, however, agreed that they were united on two issues:

1. They opposed the illegal overthrow of the government

2. They opposed all human rights violations. ${ }^{1}$

The NGOCHR succeeded in its functions as a human rights coalition as they were united in opposing all human rights violations. The events of 2007 however, revealed that the human rights NGOs in Fiji are small entities, vulnerable in times of conflict. They do not enjoy special privileges or protections that diplomatic and international organisations enjoy. Their size and specific organisational purpose means that human rights NGOs cannot spearhead a movement for return to democracy in Fiji as they would not have sufficient resources for this cause, and the activity would fall outside their core objectives.

\section{Who protested?}

The 2006 coup found NGOs feeling isolated and fighting for ideals of democracy without the backing of grassroots. PER prevented publishing of some statements and also any public support. Ordinary citizens failed to protest against the military takeover. The 1987 and 2000 coup failed to trigger mass protests because it was felt those coups were in favour of indigenous Fijians. However, Prime Minister Qarase, ousted in the 2006 coup, had won the elections through over 80 percent Fijian votes. Qarase was kept under house arrest for two days after the coup before departing for Mavana. His supporters failed to protest, and were confused by his departure. People may have protested if Qarase had decided to continue being held in captivity. But people continued living their daily lives, prioritising economic needs over civil and political ideals. 
NGOs have found themselves isolated fighting for an ideal that few want to fight for, but majority would like to enjoy - as is the case for most civil and political rights. They also felt isolated among themselves as some took a strategy of non-engagement whereas others decided to engage to find solutions.

The 2006 coup was different because it was '...in the name of "good governance", anti-corruption and anti-racism, and appealed to the rather severe moral values of Fiji's urban elites (Firth \& Fraenkel, 2009, p. 7)'. Those that advocated against the 2006 coup found themselves without former allies and without the moral public support of the grassroots. The grassroots, on their part, could be easily swayed by provision of essential services in their area by the coup-installed government-services that elected governments had neglected to provide for decades.

\section{Disunity destroys opportunities}

To take a middle ground is as difficult a task for NGOs as it is difficult for donors to understand. An opportunity to take the middle ground was presented by a proposal by John Samy for a Charter process in Fiji. NGOs were approached through CCF, as this process had a potential of delivering the best outcome to Fiji if it was driven by CSOs. CCF's own attempts to engage in dialogue with the interim regime to find a way back to democracy, was regarded with suspicion by other NGOs. NGOs were reluctant to respond to Samy's proposal for a Charter process to find a way forward for Fiji. Time was ticking by... CSOs failed to take up the Charter initiative. Instead, the Interim Government (IG) finally agreed over the concept and decided to provide space for it.

CCF, ECREA, WAC and Fem'Link were four NGOs that participated in the Charter process while other NGOs criticised and derided them. Numerous donor applications by Samy proved futile. These donor funds would have enabled the Charter process to operate independently. The Charter team disbanded in 2008. Samy could be credited for preventing a further deterioration in the Fiji situation for two years ${ }^{2}$ while the Charter process was underway, the IG strived for good governance. After disbanding of the Charter team, authoritarianism by the IG increased. Soon afterwards, the IG abrogated the 1997 Constitution - a day after the 9 April 2009 Court of Appeal judgment against its legality, and imposed Public Emergency Regulations (PER) under which human rights were severely constrained. The question remains whether 
the Charter process would have provided solutions to Fiji, if CSO's and political parties had embraced it and contributed to its development and if it was funded by independent donors.

The collapse of the Coalition for Democracy and Peace three weeks after its inception in December 2006 also provides food for thought as it was widely regarded as a good concept that recognised a variety of concerned individuals and organisations needed to join and have a united voice for a return to democracy. A lack of a long-term plan or vision and a lack of leadership caused the demise of the coalition.

Two years after the coup, on 5 December 2008, a new Movement for Democracy in Fiji was launched by eight NGOs and political parties, namely PCRC, FWRM, National Council of Women Fiji (NCWF), Fiji Islands Council of Trade Unions (FICTU), Fijian Teachers Association (FTA), United People's Party (UPP), NFP, and SDL (Fiji Times, 5 December 2008). A statement from the movement said they had '... banded together to spearhead a joint campaign plan to return Fiji to parliamentary rule and persuading the interim regime to put in place a clear and credible process and time table for elections' (Fiji Times, 5 December 2008). The movement also established a fund for the Restoration of Democracy. NFP's Attar Singh, who is also the general secretary for FICTU was named the chairperson of the movement and PCRC the secretariat (Fijilive, 2 January 2009).

The movement did not gain widespread support as it had restricted its membership to a select group of NGOs, unions and political parties. A bias towards the deposed government and animosity to those with different ideologies prevented membership from a wide group of people and caused further division within civil society.

Thus a major reason that protests against the 2006 coup did not succeed was due to the lack of unity between NGOs, CSOs, unions, political parties, and the wide variety of organisations and people who make up civil society. NGOs tend to be isolated in their fight for democracy. But the failure of ordinary citizens to protest made NGOs lose hope as did the failure of Qarase's supporters to protest. Ordinary citizens prioritised their economic needs over civil and political ideals. While most were afraid of protesting, some wanted to see if the Bainimarama interim government would deliver better basic services.

\section{Restrictions on the media}

The restriction on the media in Fiji after the abrogation of Fiji's 1997 
Constitution on 10 April 2009 eroded the progress Fiji had made on Freedom of Opinion and Expression in the public and the media. After the 1987 coup, Fiji underwent a period of repression where democracy and equal rights were harder to talk about. However, censorship of the media only happened for a short while after the 1987 coup. The media was again targeted straight after the military takeover in 2006. Military personnel moved into the newsrooms of media outlets late afternoon on December 5 and issued a directive that all news items would be screened by the military and demanded that nothing negative be aired or published against the commander, Commodore Frank Bainimarama, or his takeover (IFJ News Release, 6 December 2006). Local journalists were warned not to publish any condemnation by local and international NGOs. In response, Fiji TV did not run its $10 \mathrm{pm}$ bulletin on December 5, and no issue of The Fiji Times was published (IFJ News Release, 6 December 2006). The next day, after a meeting with senior executives of four media companies and Chairman of the Fiji Media Council Daryl Tarte, Acting Commander Esala Teleni gave an undertaking that there would be no censorship and no further interference by the military in the role of the nation's media (Democracy for Fiji campaign launched, Fiji Times, 7 December 2006). Fiji still enjoyed relatively free media under a tense political situation.

On 10 April 2009, the reinstated Bainimarama government promulgated the Public Emergency Regulations 2009 (PER) which severely restricted assembly, meetings, public gatherings and discussions in Fiji. The eight-page decree was the fifth one promulgated by the President that day, after the abrogation of Fiji's 1997 Constitution. The education, health and private sector appeared to have suffered little impact. However, NGOs, CSOs, trade unions, political parties and other bodies and individuals critical of the government now found their activities were more severely scrutinised. NGOs, CSOs, churches, unions and even private bodies now had to apply for a permit to hold a meeting or assembly. If the agenda of the meeting suggested that any 'political' issue may be discussed, then the permit would not get approved. Even $\mathrm{CCF}$, a human rights $\mathrm{NGO}$, is required to apply for permits to conduct educational workshops and public lectures.

Government 'censors' are sent to newsrooms to check stories published by daily media outlets. All stories critical of the government, military or the current status quo are ordered to be removed. Edwin Nand, a Fiji One News television reporter was arrested and detained by police for 48 hours for 
preparing a news story that the government did not like. On the weekend of 9/10 May 2009, Fijilive reporters Dionesia Turagabeci and Shelvin Chand were arrested (RNZI, 10 May 2009) and detained for a news item about the CCF (CCF, 7 May 2009) criticising the government for releasing eight soldiers and a policeman on Compulsory Supervision Orders. The men, convicted of manslaughter, were released two months after being sentenced to serve four years and four months. A Fiji Times article on the same issue managed to get printed at a later date. However, censors had the article removed from the Fiji Times website later that day. Ironically, a statement by government spokesman Lieutenant-Colonel Neumi Leweni, justifying that their release under a CSO '... is provided for by law ... and ... done in accordance with the Prisons Act' (Fijilive, 13 May 2009) was allowed to be published.

The PER is extended every 30 days and was extended again for the 17th time in August 2010 (PER extended, Fiji Times, 21 August 2010). The new extension came into effect on August 24. The Media Industry Development Decree 2010, promulgated by the Fiji government on 25 June 2010, entrenches censorship as journalists and media organisation heads can be fined or jailed for publishing certain types of news. The ordinary citizens living in rural areas of Fiji, who were already disadvantaged in receiving news and information because of a lack of infrastructure and access to communications technologies, now face a further disadvantage in Fiji because the censorship means they can only hear what the government approves of or wants them to hear or see in the newspapers, radio or television. In fact, everyone in Fiji now can only hear or see news that is approved by the government. By restricting the Right to Information through censorship, the Fiji government is effectively preventing any meetings or information dissemination that could assist in forging alliances to fight for a return to democracy. Without a free media, it is very difficult for Fiji to return to democracy. If ordinary citizens do not fight, then free media also may not return for a long time.

\section{Infrastructure and democracy}

Looking at theories of modernism, post-modernism and neo-colonialism, Fiji is still in a development stage. While flourishing democracies in the world are in an era of post-modernism - whereby they have achieved modernity through the phase of industrial revolution, technological development, and advanced infrastructure and communication facilities that makes travel and communication a readily available activity, Fiji has not yet comple- 
ted this phase of development. Fiji is in a phase of modernity where the infrastructure is still being built. One only has to drive less than two hours away from the capital, Suva, and they are transported to a rural area such as Viria, Vunidawa and Naluwai in Naitasiri, and Naisausau and other villages in Tailevu, off the Korolevu highway. Here, people still live semi-subsistence, modest lives. There is no tarsealed roads in the interior and only scarce bus services. There are problems of water and electricity supply. There are no supermarkets and availability of goods for purchase is only through small shops with limited supplies. Some villages located two hours from Suva city have never had electricity.

Visits to the Namosi provincial highlands, the interior of Sigatoka, Nagado and other villages located less than an hour's drive from the jet-set Nadi tourist town, reveal a similar scenario. ${ }^{3}$ The story is the same for the second largest island, Vanua Levu whether one travels to Seaqaqa, Batanikama and other villages in Labasa, or to Viani and other coral coast villages in Savusavu, or to the other islands Ovalau and Taveuni.

A Community Submission to the 2010 Budget, made by CCF in July 2009 (CCF, 2009) highlighted that people in very different localities in Fiji identified needs that were similar, and which had been in existence for many decades. CCF has conducted grassroots education workshops on the National Budget since 2006 in Suva, Lautoka, Labasa, Savusavu, Levuka, Korovou, Navua, Sigatoka and Taveuni. These needs include: roads, regular transportation, health centre with qualified staff and equipment, water supply that is also clean, farming and agricultural assistance, vocational training schools, and stable electricity supply. Roads were identified as a common concern as it was a root cause of their problems. Without roads, they have difficulty accessing services such as health care, schools, jobs, and market for farm produce. Many of the problems highlighted are synonymous with similar problems in rural areas around Fiji.

Fiji's situation is similar to many other Pacific Island countries which are undergoing a process of modernisation. Historians have also described this as neo-colonialism, whereby institutional structures of bureaucratic systems, parliamentary methods, Christianity, and village organisation structures left behind by colonisers are still operational. Apart from the French territories, most Pacific Islanders have not fought for independence and democracy. Fijians did not struggle for democracy.

During the phase of modernisation, countries go through an industrial 
revolution which involves rapid development and growth. Most importantly, they also go through a phase of civil and political awakening, the end result of which is normally a political situation whereby the ordinary citizens have more say in the affairs of their country. In the European countries of Britain, France and Ireland, this is evident. In fact, the modernisation phase in Europe was accompanied by colonisation and resettlement of other parts of the world and the spread of Christianity. In big developing countries of the world, such as India and China, while there are segments of urban parts of the country that are flourishing in 'post-modernity', the bulk of their rural areas are still undergoing modernisation. This has resulted in democracy not being able to function properly in these technologically advanced developing countries.

According to the Commonwealth Human Rights Initiative (CHRI), four common problems impede development and democracy in the Commonwealth: the inequality of power between government and the citizen; the consequent lack of accountability and near impunity of politicians and public officials; corruption; and exclusion of the public from participating in decisions that affect their lives (CHRI, 2003, p. 75). CHRI recommends that open governance and assured access to information offer the key to address these complex issues.

Information must be harnessed to create short cuts to development and democracy. It must be shared equitably and managed to the best advantage of all members of society. The means are available but sadly the will is often not. It is an indictment of the Commonwealth that so many member states continue to fail to live up to the democratic ideals that are reflected in the commitment to the right to information (ibid.).

Fiji is one of the most developed Pacific Island Countries (PICs). However, major parts of the country has limited or no access to electricity, tap water, roads and reliable transport. In urban and peri-urban areas, television, newspapers, magazines, internet, and other sources of information are available. Radio in the vernacular language, remains the most effective means of communication as newspapers and magazines rarely reach remote areas, and lack of electricity and economic means rules out internet.

The developed world is at an advanced stage with democracy where the population can choose to be fully informed to take part in democratic decision-making. The lack of a similar choice to be informed in Fiji means leaders have more opportunity to make decisions which may not be in the 
best interests of citizens. Ordinary citizens end up being bystanders, at the receiving end of policies they had little input in, grappling to understand the bad consequences of failed government activities. Where the decisions are made by coup-makers, citizen apathy is greater.

Not knowing better, citizens decide to stand by and not take any action thinking, 'What would I do with democracy if there is no food on the table?'

\section{The question of rights}

The preamble to the International Covenant on Economic, Social and Cultural Rights (ICESCR) states '.... Recognising that, in accordance with the Universal Declaration of Human Rights, the ideal of free human beings enjoying freedom from fear and want can only be achieved if conditions are created whereby everyone may enjoy his economic, social and cultural rights, as well as his civil and political rights'.

The 1945 Charter of the United Nations, the International Covenant on Civil and Political Rights (ICCPR) as well as other major international law documents, recognise the importance of the realisation of economic, social and cultural rights in order for civil and political rights to be enjoyed. These two categories of rights are interdependent.

Inherent to the realisation of economic, social and cultural rights are the right to work freely, fair wages, decent living, safe and healthy working conditions, rest and leisure, the right to join unions and strike, the right to social security, protection and care for the family including education of children and protection of mother. The ICESCR, most importantly also provides under Article 11 'the right of everyone to an adequate standard of living for himself and his family, including adequate food, clothing and housing, and to the continuous improvement of living conditions'. Article 13 provides for the right to education which 'shall be directed to the full development of the human personality and the sense of its dignity, and shall strengthen the respect of human rights and fundamental freedoms'. Further, education is expected to '...enable all persons to participate effectively in a free society...'

The realisation of economic rights are recognised as essential to the development of a person to enjoy their civil and political rights, as vice versa. Over 40 percent of Fiji's population live in poverty. Those slightly above the poverty line, and those living in semi-subsistence situation in rural and peri-urban areas may be able to meet basic needs but not much more. Those 
living in rural and interior areas, where roads are bad and transport irregular, find it difficult to access basic services such as health care and government facilities. A single errand to main government centres can take a day, or more to achieve. They cannot be expected to be readily available to participate in democratic processes. In fact, most people living away from the urban centres feel disconnected to what is happening in the government and in the capital Suva.

There needs to be more education on the true spirit of democracy, which provides for everyone's rights, needs, and identities to be respected. This will enable better understanding by voters of the process of governance and how voting fits into the control over state power. People will then understand why their civil and political rights are important and how it can be utilised to make democracy work through articulation of their demands for resources and development for their communities. More education on governance, citizenship, human rights and democratic processes are also necessary for creation of a common sense of identity in the diverse ethnic groups in Fiji. Here again, a lack of unity among Fiji's leaders has contributed to stronger identity with one's ethnicity, rather than the nation. When people understand their democratic power, coups will be virtually impossible to be carried out.

\section{Inadequate funds for infrastructure needs}

The development of infrastructure and communications is essential to the realisation of economic as well as civil and political rights. 'Fiji- - The State of the Nation and the Economy Report' (NCBBF, August 2008, p. 9) reveals that increasing government debt with higher payments for interest has preempted funds for vitally needed infrastructure such as water, roads, sewerage, electricity and housing. The report reveals Fiji's Economic Growth has been on a slow downward curve since 1970. It emphasises that the 'government's involvement in the economy should focus first on the provision of public goods, which by their nature cannot be supplied by anyone else. It is clear that at present, the demand for basic utilities such as water, sewerage, electricity, telecommunications and other infrastructure (such as roads, ports and airports) is not being satisfactorily met' (p. 27). The report highlights the weak service delivery in the public sector as a 'serious constraint on national development and that is adversely affecting the lives of many of Fiji's people, particularly the poor and the vulnerable' (p. 33).

The Asian Development Bank (ADB) notes (ADB, 2010) 'only about 
50 percent of the population has access to safe water and proper sanitation. Access to sanitation is 75 percent for urban areas, and only 12 percent for rural areas'. ADB states that, 'most of the country's public external debt ... comprised official multilateral loans from ADB, European Investment Bank, and International Bank for Reconstruction and Development. ADB contributed about 73 percent of these loans.' The major project of the Rewa Bridge (Qarase, 26 February 2004) construction was made possible through $\$ 24$ million aid from the European Union (EU). In 2005, under Fiji's road upgrading programme (Chand \& Cula, 10 August 2005), the ADB, World Bank and the Exim Bank of Japan co-funded projects up to $\$ 118$ million in Viti Levu and Vanua Levu.

In 2004 (MoF, 2003, p. 89), the government allocated more than \$31 million for infrastructure projects. In 2009 (PWC, 2008, p. 26), the Interim Government allocated $\$ 38.30$ million for infrastructure and works. The 2004 elected government received large donor funds enabling it to spend a further $\$ 19$ million on the EU funded Rewa Bridge and Kinoya Outfall Project, and the Chinese-funded Navuso Linking Bridge (MoF, 2003, p. 108). While the Interim Government allocated more for infrastructure in 2009 , it lost out on donor-funded major infrastructure projects, which is revealed through the allocation of only $\$ 4.3$ million for the Navuso Bridge and the Somosomo Mini Hydro Scheme (MoF, 2008, p. 56). These infrastructure projects are in addition to the normal roads and infrastructure maintenance work carried out by the government each year. The high reliability of new infrastructure development projects on foreign aid means that the normal government budget allocation each year is sufficient to maintain infrastructure only-it is not sufficient to create major new infrastructure development. It may be many more decades before basic services, infrastructure and knowledge technology, essential to democracy become available throughout Fiji.

\section{Conclusion}

Democracy has failed to work properly in Fiji because parts of the country are still undergoing a process of modernisation. The struggle for democracy has yet to occur in Fiji. Protests against coups has largely been by the educated middle class where the CSOs activists and politicians tend to come from. Bad leadership has contributed to a lack of development in Fiji and to the coup culture, as has the gap between the middle class and ordinary citizens. For true democracy to be achievable in Fiji, infrastructure and communications technology needs to reach the masses. This will enable creation of 
a knowledgeable society. There needs to be adequate realisation of economic rights of people, as this is essential to the realisation of civil and political rights. There needs to be a free media for ordinary people to know what is happening and for dissemination of information for creation of alliances and holding the government accountable.

Alison Lazarus, former director of the Peace Building and Development Institute at the UNDP Pacific Centre, once said: 'For the people to govern, the people need to remain engaged. The citizen has to stay vigilant to her own needs and hold government accountable for delivery' (Lazarus, 2007). Lazarus argues that the

\begin{abstract}
strategy of cooperation and non-cooperation too has its time and its limits. There was only so long that people will boycott and disengage the state. For always people just want to live and learn and get on with their lives ... if the root causes of conflict are not addressed ... times of withdrawal are often the time for rearming and reconstituting one's forces to live to struggle and fight another day.
\end{abstract}

A new movement is needed in Fiji with a visionary, inspirational leadership and a simple objective, inclusive and open to people from any political, social, economic, religious or ethnic background to join freely. Such a movement would transcend the CSOs, ethnic, political or other ideological divides. José Ramos-Horta and Mahatma Gandhi's example reveal it is important to be open to talk to everyone with different beliefs for democracy to be achieved. When the time is right and an opportunity is presented, the citizens must not remain a bystander but engage. For after all, a country is only as good as its citizens and a democracy can only work if all people in the country take the responsibility to make it happen.

\title{
Notes
}

1. Human rights has formed the basis of most media statements from the NGOCHR in the aftermath of the 5 December 2006 coup.

2. Author's viewpoint as an internal observer of the process.

3 . These areas have been visited by the author while conducting education workshops for Citizens' Constitutional Forum CCF, where she is employed.

References

Asian Development Bank, 2010, Country Strategy and Program Update 20062008: Fiji Islands, Republic of the, III. Implementation of the Country Strategy 
and Program. Retrieved on 13 July 2010, from www.adb.org/Documents/CSPs/ FIJ/2006/csp0300.asp

Chand, S., (2009). On a rocky road of coups to democracy in Fiji. Unpublished paper, School of Business, University of New South Wales @ the Australian Defence Force Academy, June 1.

Chand, V., Cula, F., (2005, August 10), North geared up for economic activities, Feature on Fiji Government Online.

Citizens' Constitutional Forum (CCF). (2009, May 7). Release on CSOs of soldiers convicted of manslaughter undermines justice [Media Release], Suva. Retrieved on 13 July 2010, from www.ccf.org.fj

Citizens' Constitutional Forum (CCF) (2009). Community Submission to the Ministry of Finance and National Planning for the 2010 Budget. Retrieved on 13 July 2010, from www.ccf.org.fj/submissions.php?PHPSESSID=59fdbddb7661c94da e27ebd45511b4f6

Commonwealth Human Rights Initiative (CHRI). (2003). Concluding recommendations. In Open Sesame: Looking for the Right to Information in the Commonwealth, CHRI, New Delhi. Retrieved on 13 July 2010, from www.humanrightsinitiative. org/publications/chogm/chogm_2003/recommendations.pdf

Democracy for Fiji campaign launched. (2008, December 5). Fiji Times Online. Retrieved on 13 July 2010, from www.fijitimes.com/story.aspx?id=108150

Fiji Government. (2009, April 10). Public emergency regulations 2009, Republic of Fiji Islands Government Gazette, Acting Government Printer, Suva.

Fijilive. (2009, January 2). Singh heads democracy movement. Retrieved on 13 July 2010, from www.fijilive.com/news_new/index.php/news/show_news/12245

Fijilive. (2009, May 12). Release of soldiers, police 'legal'. Retrieved on 13 July 2010, from www.fijilive.com/news new/index.php/news/show news/16125

Firth S., and Fraenkel J. (Eds.) (2009). The enigmas of Fiji's good Governance coup. In Fraenkel J., Firth S., \& Lal B.V. (Eds.), The 2006 military takeover in Fiji - A coup to end all coups? (pp. 3-17). Canberra: The Australian National University E-Press.

International Federation of Journalists (IFJ). (2006, December 6). Crackdown on press freedom in Fiji [IFJ News Release], Sydney. Retrieved on 13 July 2010, from from Pacific Islands Report http://pidp.eastwestcenter.org.

Kabeer, N. (Ed.) (2005). Inclusive citizenship - meanings and expressions. London \& New York: Zed Books.

Lazarus, A. (2007). The people shall govern-citizenship and constitutionalism in South Africa, Speech at public lecture, organised by the Citizens' Constitutional Forum, Suva, Fiji, March.

Military says no more interference with media. (2006, December 7). The Fiji Times. Retrieved on 13 July 2010, from Pacific Islands Report http://pidp.eastwestcenter. org.

Ministry of Finance (MoF). (2003, November 7). Republic of Fiji-supplement to the 2004 Budget Address, Ministry of Finance, Republic of Fiji Islands.

Ministry of Finance (MoF). (2008, November). Republic of Fiji-supplement to the 2009 Budget Address, Ministry of Finance, Republic of Fiji Islands. 


\section{MEDIA FREEDOM IN OCEANIA}

PER extension. (2010, August 21). Fiji Times Online [In Briefs]. Retrieved on 13 July 2010, from www.fijitimes.com

PriceWaterHouseCoopers (PWC), 21 November 2008, 2009 Fiji Islands Budget Summary - by PriceWaterHouseCoopers.

Qarase, L. (2004, February 26), PM's remarks at ground breaking ceremony for the new Rewa Bridge. Prime Minister and Minister for Fijian Affairs, Culture \& Heritage; Minister for National Reconciliation \& Unity; and Minister for ALTA \& Sugar Industry Reform., Retrieved on 13 July 2010, from www.fiji.gov.fj/cgi-bin/ cms/exec/view.cgi/42/2022/printer

National Council for Building a Better Fiji (NCBBF) (2008, August). Fiji- the state of the nation and economy report. Suva: National Council for Building a Better Fiji (NCBBF).

Radio New Zealand International. (2009, May 10), Two journalists detained in Fiji. Retrieved on 13 July 2010, from www.rnzi.com/pages/news.php?op=read\&id=46470

Ravuvu, A. (1991). The façade of democracy-Fijian struggles for political control 1830-1987. Suva: Institute of Pacific Studies, University of the South Pacific.

Shameem, S. (2007, January 4). The assumption of executive authority on December 5th 2006 by Commodore J. V. Bainimarama, Commander of the Republic of Fiji Military Forces: Legal, Constitutional and Human Rights Issues, Suva, Fiji: Director, Fiji Human Rights Commission.

Yabaki, A. (2009). Making votes count. In Fraenkel J., Firth S., \& Lal B.V. (Eds.), The 2006 military takeover in Fiji- a coup to end all coups? (pp. 397-404). Canberra: The Australian National University E-Press.

Mosmi Bhim is an advocate for the Citizens' Constitutional Forum (CCF) in Suva, Fiji. The views expressed in this article are the author's and do not reflect the views of CCF. The author acknowledges the support and encouragement from Dr Jon Fraenkel and Dr Stewart Firth at the Australian National University. An earlier version of this article was presented at the Australian Association for the Advancement of Pacific Studies conference in Melbourne, 8-11 April 2010.

mosmi_bhim@hotmail.com 
Copyright of Pacific Journalism Review is the property of Auckland University of Technology and its content may not be copied or emailed to multiple sites or posted to a listserv without the copyright holder's express written permission. However, users may print, download, or email articles for individual use.

http://www.aut.ac.nz/depts/commstud/journ/pjrsubs.shtml 